JAMA. 2016 October 11; 316(14): 1449-1450. doi:10.1001/jama.2016.8186.

\title{
Systemic paradox
}

\author{
Lisa M Bebell, MD ${ }^{1,2, \S}$ \\ ${ }^{1}$ Division of Infectious Diseases, Massachusetts General Hospital, USA \\ ${ }^{2}$ Massachusetts General Hospital Global Health Collaborative, USA
}

Mr. Childs kept losing weight. Every time he came to my office, he would greet me with a hug, and I would count more ribs through his piled-on shirts and sweaters. He was always cold. And his pulse was racing, trying to outpace the disease slowly consuming him. Aside from the wasting disease, coughing was his only sign of illness, and fatigue dominated his days. After a year spent scouring Mr. Childs' body for clues, we still didn't know what that disease was. Being the subject of so many tests prompted Mr. Childs' joking he would start charging me a "pin cushion rate." Though wasting away from visit to visit, he was invariably in good spirits and his faith in my powers of diagnosis and healing never faltered. "You're the best doc I've ever had, Dr. Bebell," Mr. Childs would say, "I want everything to go through you, because I want everyone on the same page. You're the only one who can make that happen."

He was right, about some things. In our healthcare system, a primary care doctor like myself plays the role of gatekeeper, manager, and coach. I act as the proverbial cat herder of specialist physicians, physical and occupational therapists, pharmacists, family members, and every other Tom and Harry involved in my patient's care. It's my job to make sure that the right information is gleaned and shared with the right people, in the right time frame. Even as he sat in my office, I was fielding pages and emails about Mr. Childs to and from three pulmonary specialists, a thoracic surgeon, an oncologist, a social worker, a pharmacist, an over-exuberant home health worker, an inpatient medicine doctor, a pathologist, and many other people who constituted his healthcare 'team.' This jumble of healthcare professionals operated more like an accidental pick-up soccer league, whose members subscribed to different rules without speaking the same language. None of Mr. Childs 'team' had spoken to each other about Mr. Child's case - rather, it all went through me, just as Mr. Childs hoped. We were allied by a single mystery - what was killing our patient. We raced the clock separately and in parallel, aching to uncover what was in Mr. Childs' lungs. His invisible foe opened the door to three bouts of pneumonia in less than a year - each successive round peeling off another layer of his dignity and his frame. I now locked eyes with a Mr. Childs 30 pounds lighter than the day we met, his pale green eyes leveling me with a new intensity, pleading for my help.

I held his hand, felt his pulse quiver beneath my fingertips. I did not know what to say. In lieu of perfect words, I said the only words that felt certain - I would do my best. I kept my

\footnotetext{
$\S$ Corresponding author: Lisa Bebell, M.D., Massachusetts General Hospital, 55 Fruit Street, Department of Infectious Diseases, GRJ-504, Boston, MA 02115, United States of America, Phone: (617) 726-3812, lbebell@ mgh.harvard.edu.
} 
promise, overbooking Mr. Childs monthly into my already-overbooked afternoon clinic just so I could lay eyes on him, to see what substance remained. I had to see him almost selfishly - to convince myself he was okay, though in limbo he was actually alright. In reality, he wasn't. I think we both knew his body was failing, but it comforted us both to deny it. Like survivors on the Titanic, we wanted the music to play right to the end.

I plied colleagues and machines, looking for answers. Four diagnostic procedures came and went, including an open lung biopsy, and we still didn't know what was going on. I was desperate to get Mr. Childs a diagnosis, more so than I had ever been. Our last hope was to send Mr. Childs to the academic medical center affiliated with our county hospital. There, he would undergo a high-risk procedure to wrench out a piece of the mass in his left lung, nestled right next to his heart. Was it some bizarre pneumonia whose escape tunnel had long since been cut off? A deeply lodged fungus ball? A benign but inflamed soft tissue mass? Or, was it cancer? Mr. Childs and I, we had to know. And that meant getting a piece of it.

The decision to sample the mass was an easy one - so strong was our desire for the truth. In practice, the act of it was near-impossible. Mr. Childs was uninsured, and had no way of paying for the procedure. We had to work the system. I hustled to get him emergency Medicaid, health coverage for poor people in desperate situations. Surely he would qualify -we had no other options. I filled out endless pages of paperwork required to justify Mr. Childs' case. I reached deep, massaged the truth and made some lightly-grounded assumptions in order to make his case. Please, I thought, just give us one more chance. A few weeks went by, and at our monthly visit I was taken in by Mr. Child's eyes, which gazed upon a stormy sea. I chased his Medicaid application by phone, so familiar with the hold music I hummed along. At last, the Medicaid office sent Mr. Childs an enrollment card. So strange, how a piece of colored plastic can change two lives in an instant. I almost jumped with joy, and began to see a ray of hope for Mr. Childs' future. It had been a year of attempts to diagnose this wasting disease, and now it felt like there was still time to make a diagnosis, find a cure, and get Mr. Childs back to his life, his family. We searched the system for a solution, and we were rewarded.

As I madly began the process of referring Mr. Childs to our academic center, he came down with another bout of severe pneumonia. He was feverish, sweaty, weak, and coughing so forcefully it racked his emaciated frame, pressing ribs out at odd angles. I visited him in the hospital ward after he was admitted. Oxygen tubes threaded around his neck and into his nose, easing his breathing, and IVs poured vital fluid and potent antibiotics into his veins. I sat down on the edge of his bed and held his hand. "I coughed it up, doc." "I know," I said, squeezing his hand tighter. We were both silent for a moment, tears sliding down our cheeks. After he was admitted, as a last resort the hospital's pulmonary specialist had decided to do a relatively primitive, low-tech test that succeeded where technology had failed-and made the diagnosis. Mr. Childs had been asked to cough up a sputum sample, and lying there, naked under the microscope, was advanced cancer.

I knew immediately the cancer was not curable. But there was still hope that Mr. Childs could feel better, shrink the tumor, squeeze out a few more good months to live. He needed a brand-name chemotherapy pill recommended by his oncologists. As he was discharged from 
the hospital, the drug was prescribed for him, through all the proper channels. Mr. Childs tirelessly went to pharmacy after pharmacy, but each one repeated the same mantrabecause he now had Medicaid, Mr. Childs was no longer eligible for pharmaceutical assistance plans for the uninsured. He was going to have to pay a deductible to get the medication-a deductible of $\$ 6,000$.

Mr. Childs called me, breathless. I was floored. He clearly could not afford a $\$ 6,000$ copay using the disability income we secured for him through several months' paperwork. He was devastated. Over the next month, I worked nearly every day to get Mr. Childs' Medicaid reversed, to acquire a generic chemotherapy pill, get the brand name more cheaply, anything. For one month, Mr. Childs went without his life-prolonging therapy, losing weight, near his wits' end, unable to sleep. The sad irony of this mess weighed heavily on me. Inadvertently, my attempts to get Mr. Childs a faster diagnosis had led to exorbitant expense for him and no treatment at all. I reflected on the point we reached, feeling I had failed in my role as coordinator and coach, despite all my best efforts. It took me a few weeks of reflection and hold music to realize that Mr. Childs and I were not the drivers of this year-long roller coaster. Our healthcare system had failed us both, granting Mr. Childs additional privileges and rights after we fought tenaciously for them, but then paradoxically denying him needed therapy . In a world where appropriate healthcare is a privilege and not a right, good health really seemed only to come from wealth. Accepting this truism gave me a strange kind of peace, but also made me angrier than ever.

When he came to see me next, Mr. Childs had finally started the brand-name chemotherapy pill, after another month's hard work by the oncology social worker. This small victory was swallowed by the deep shadow of the prior day's news-Mr. Childs had been told by the cancer specialists that his lung cancer had now metastasized to his liver. The system had defeated us. "You did everything you could, doc," he said in my office that day, holding my hand. "You're more than just my doc, you're also my friend." After he left my office, parting ways with a last bony hug, I sat with his chart in my hand and cried.

\section{Acknowledgements}

The author declares no conflict of interest and acknowledges the following sources of support: NIH T32AI007433 (Bebell) and NIH Research Training Grant R25TW009337 funded by the Fogarty International Center and the National Institute of Mental Health (Bebell). 